\title{
Moderately prolonged dry intervals between precipitation events promote production in Leymus chinensis in a semi- arid grassland of Northeast China
}

Jinwei Zhang ${ }^{1+}$, Xiangjin Shen ${ }^{2+}$, Bifan $\mathrm{Mu}^{3}$, Yujie Shi ${ }^{1}$, Yuheng Yang ${ }^{1}$, Xuefeng $\mathrm{Wu}^{1}$, Chunsheng $\mathrm{Mu}^{1 *}$ and Junfeng Wang ${ }^{1 *}$ (D)

\begin{abstract}
Background: Climate change is predicted to lead to changes in the amount and distribution of precipitation during the growing seasonal. This "repackaging" of rainfall could be particularly important for grassland productivity. Here, we designed a two-factor full factorial experiment (three levels of precipitation amount and six levels of dry intervals) to investigate the effect of precipitation patterns on biomass production in Leymus chinensis (Trin.) Tzvel. (a dominant species in the Eastern Eurasian Steppe).

Results: Our results showed that increased amounts of rainfall with prolonged dry intervals promoted biomass production in L. chinensis by increasing soil moisture, except for the longest dry interval ( 21 days). However, prolonged dry intervals with increased amount of precipitation per event decreased the available soil nitrogen content, especially the soil $\mathrm{NO}_{3}{ }^{-}-\mathrm{N}$ content. For small with more frequent rainfall events pattern, $\mathrm{L}$. chinensis biomass decreased due to smaller plant size (plant height) and fewer ramets. Under large quantities of rain falling during a few events, the reduction in biomass was not only affected by decreasing plant individual size and lower ramet number but also by withering of aboveground parts, which resulted from both lower soil water content and lower $\mathrm{NO}_{3}{ }^{-}-\mathrm{N}$ content.

Conclusion: Our study suggests that prolonged dry intervals between rainfall combined with large precipitation events will dramatically change grassland productivity in the future. For certain combinations of prolonged dry intervals and increased amounts of intervening rainfall, semi-arid grassland productivity may improve. However, this rainfall pattern may accelerate the loss of available soil nitrogen. Under extremely prolonged dry intervals, the periods between precipitation events exceeded the soil moisture recharge interval, the available soil moisture became fully depleted, and plant growth ceased. This implies that changes in the seasonal distribution of rainfall due to climate change could have a major impact on grassland productivity.
\end{abstract}

Keywords: Climate change, Rainfall patterns, Grassland productivity, Soil nitrogen, Drought stress

\footnotetext{
* Correspondence: mucs821@nenu.edu.cn; wangjf150@nenu.edu.cn

†Jinwei Zhang and Xiangjin Shen contributed equally to this work.

'Key Laboratory of Vegetation Ecology, Ministry of Education, Institute of

Grassland Science, School of Life Sciences, Northeast Normal University,

Changchun 130024, P.R. China

Full list of author information is available at the end of the article
}

(C) The Author(s). 2021 Open Access This article is licensed under a Creative Commons Attribution 4.0 International License, which permits use, sharing, adaptation, distribution and reproduction in any medium or format, as long as you give appropriate credit to the original author(s) and the source, provide a link to the Creative Commons licence, and indicate if changes were made. The images or other third party material in this article are included in the article's Creative Commons licence, unless indicated otherwise in a credit line to the material. If material is not included in the article's Creative Commons licence and your intended use is not permitted by statutory regulation or exceeds the permitted use, you will need to obtain permission directly from the copyright holder. To view a copy of this licence, visit http://creativecommons.org/licenses/by/4.0/ The Creative Commons Public Domain Dedication waiver (http://creativecommons.org/publicdomain/zero/1.0/) applies to the data made available in this article, unless otherwise stated in a credit line to the data. 


\section{Background}

Water availability is the primary constraint to plant productivity in arid and semi-arid ecosystems [1, 2], and it will be strongly affected by ongoing and future climate change [3]. The availability of soil water for plants is regulated by both the amount and distribution of precipitation [1-3]. Currently, intensive research has revealed that grassland productivity is strongly positively correlated with the amount of precipitation [1, 4]. However, for a given site, the relationship is not always linearly correlated $[5,6]$ because of the variation in the distribution of precipitation events within the growing season [7].

Climate change scenarios predict significant alterations in the amount and distribution of precipitation in arid and semiarid ecosystems, which may result in changes to plant productivity $[8,9]$. In general, small and tightly clustered precipitation events evaporate rapidly and only wet the surface soil, which exerts a limited effect on plant productivity [10]. However, it can promote productivity in shallow-rooted plants, such as bunchgrass [11]. Intermediate intervals between moderate precipitation events may trigger a series of shorter periods of biomass production as the soil begins to dry between these events; however, the available soil moisture will not become fully depleted unless the interval between precipitation events exceeds the soil moisture recharge interval. When the available soil water supply becomes fully depleted, biomass production ceases [12, 13]. When larger precipitation events occur, the deeper penetration of soil water into the profile and the lower proportional loss to evaporation increases the amount and duration of water in the soil for plant uptake [1, 14-16]. In addition to being limited by soil moisture, soil nutrient content is inherently low in arid ecosystems and potentially limiting to plant growth $[13,17]$. Precipitation can directly influence soil nutrients through leaching and runoff. Frequent large rainfall events will increase the potential for loss of soil nutrients through leaching, with the nutrients accumulating in deep soil layers below the rooting zone in arid ecosystems [18, 19]. Meanwhile, soil nutrients can also be indirectly affected by vegetation absorption $[20,21]$. Therefore, the responses of plant growth to changes in rainfall patterns may be affected by both soil water and nutrient availability [7, 13, 17, 22].

Leymus chinensis (Trin.) Tzvel. is a dominant perennial rhizome grass widely distributed in the Eastern Eurasian Steppe from North Korea to Mongolia and Northern China and north-westward to Siberia [23]. This grassland area is about $4.2 \times 10^{5} \mathrm{~km}^{2}$, and L. chinensis accounts for $80-90 \%$ of the grassland's productivity [24]. In addition to its wide distribution and high yield, L. chinensis also has high forage quality (19.5\% crude protein, $3.1 \%$ crude fat, $35 \%$ crude fiber, and $6 \%$ ash) for cattle and sheep [25]. The change in L. chinensis yield is closely related to local ecosystem health and livestock production $[26,27]$. As a typical semi-arid grassland, $L$. chinensis grassland productivity is regulated by precipitation patterns $[4,26,28]$. Previous research has revealed that the possible reasons for the variations in $L$. chinensis grassland productivity caused by the amount of rainfall are shifts in the size of individual plants size or density of L. chinensis [4]. However, the influence that the dry intervals between rainfall events on L. chinensis grassland productivity is still unclear.

Rainfall patterns are currently changing and are predicted to continue changing with global warming [3]. A deeper understanding of the impacts of rainfall amounts and intervals on dominant species is essential for predicting grassland productivity due to future variation in rainfall patterns. In this study, experiments were carried out to investigate the response of $L$. chinensis to changes in long-term averages as well as inter-annual variation in rainfall amounts and intervals. The first objective of this study was to quantify how L. chinensis growth varied in response to precipitation pattern changes. Because the effects of precipitation patterns on plant growth are likely due to the direct effects of altered soil moisture and nutrients, the second objective of this study was to investigate the underlying mechanisms of L. chinensis growth responses to precipitation pattern changes by quantifying the effects of soil moisture and nutrients on plant growth. Based on the above research we propose the two hypotheses. 1) Small and tightly clustered precipitation events only wet the surface soil and evaporate rapidly, and exhibit a limited effect on plant productivity. However, moderately prolonged intervals with larger rainfall events will enhance soil moisture in both shallow and deep soil layers, and will further improve plant growth. 2) Under conditions of extremely prolonged dry intervals, soil moisture becomes a fully depleted factor because the very low levels of moisture in the soil between rainfall events exceed plant tolerance, and lead to plant growth ceasing.

\section{Results}

Effects of rainfall treatments on plant biomass production and allocation

Changes in the amount of rainfall and the length of the dry intervals had significant main effects on aboveground biomass and belowground biomass (Table 1). With increases in rainfall amounts, aboveground biomass and belowground biomass significantly increased, except for the 21 days dry interval treatment (Fig. 1). As the length of the dry intervals extended, aboveground biomass and belowground biomass showed a monopeak curve (Fig. 1). The maximum values of aboveground biomass were $139 \mathrm{~g} \mathrm{~m}^{-2}$ under the 15 days dry interval 
Table 1 Results (F-values) of two-way ANOVAs for the effects of rainfall amount and dry interval on plant traits and soil properties

\begin{tabular}{|c|c|c|c|c|c|c|}
\hline & \multicolumn{2}{|l|}{ Amount } & \multicolumn{2}{|l|}{ Interval } & \multicolumn{2}{|c|}{ Amount $\times$ Interval } \\
\hline & $F$ & $p$ & $\mathrm{~F}$ & $p$ & $F$ & $p$ \\
\hline \multicolumn{7}{|l|}{ Plant traits } \\
\hline Height & 42.81 & $<0.001$ & 20.91 & $<0.001$ & 3.47 & 0.001 \\
\hline Number of ramets & 9.95 & $<0.001$ & 9.33 & $<0.001$ & 1.17 & 0.330 \\
\hline Aboveground biomass & 120.69 & $<0.001$ & 77.62 & $<0.001$ & 11.12 & $<0.001$ \\
\hline Belowground biomass & 34.87 & $<0.001$ & 2.79 & 0.026 & 4.25 & $<0.001$ \\
\hline$R / S$ & 4.00 & 0.024 & 5.00 & 0.001 & 2.28 & 0.026 \\
\hline$S / L$ & 8.39 & 0.001 & 22.18 & $<0.001$ & 2.93 & 0.005 \\
\hline \multicolumn{7}{|l|}{ Soil properties } \\
\hline $\mathrm{NH}_{4}{ }^{+}-\mathrm{N}$ content & 6.44 & 0.003 & 8.48 & $<0.001$ & 0.34 & 0.964 \\
\hline $\mathrm{NO}_{3}{ }^{-}-\mathrm{N}$ content & 51.08 & $<0.001$ & 77.93 & $<0.001$ & 3.99 & $<0.001$ \\
\hline Available phosphorus & 3.33 & 0.043 & 5.67 & $<0.001$ & 0.40 & 0.940 \\
\hline Soil water content & 3971.40 & $<0.001$ & 3230.97 & $<0.001$ & 74.44 & $<0.001$ \\
\hline
\end{tabular}

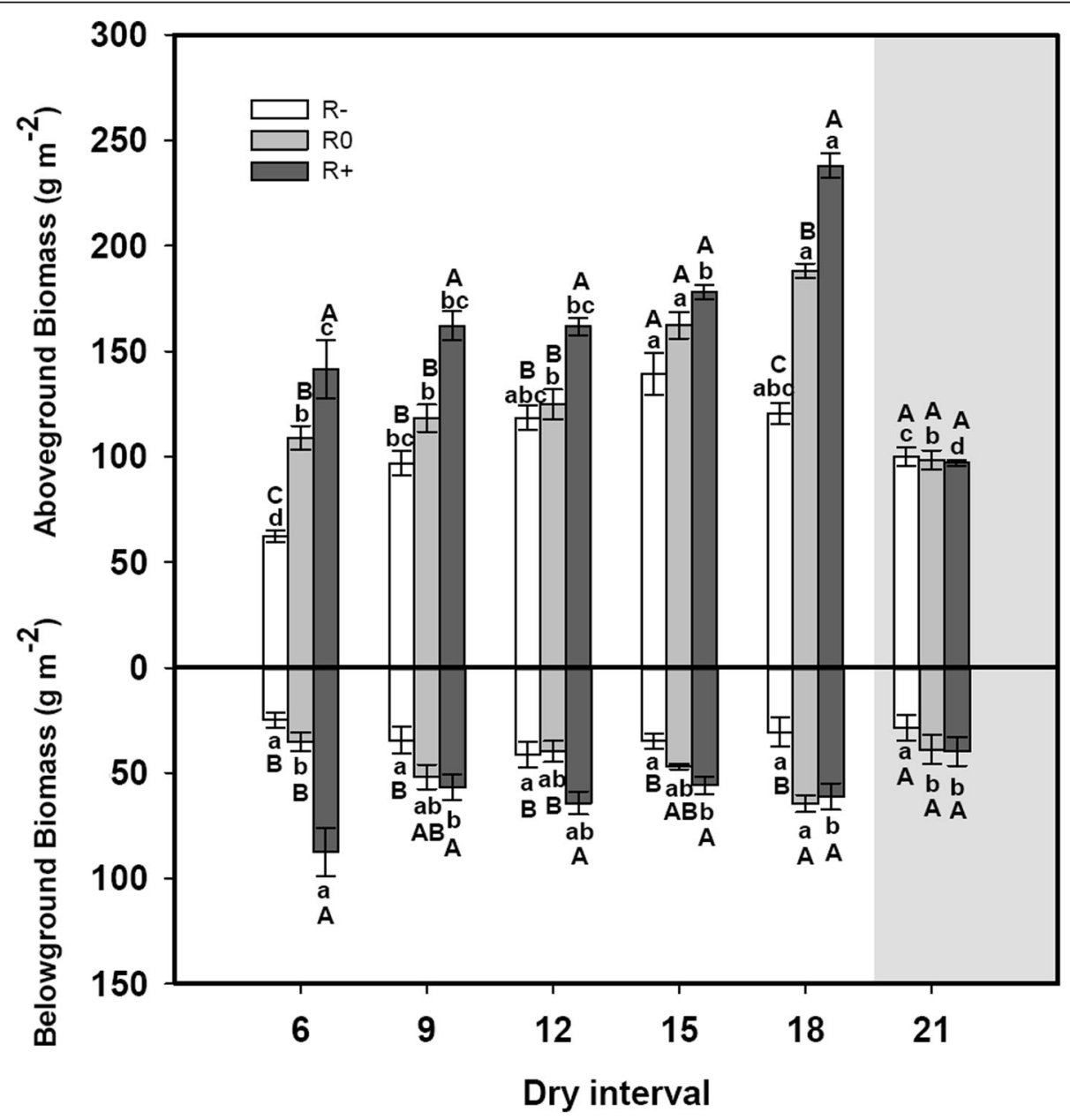

Fig. 1 Responses of $L$. chinensis aboveground biomass and belowground biomass to the variation in rainfall amounts and dry intervals. The values at each dry interval are the means \pm SE $(n=4)$. Capital letters indicate significant differences $(p<0.05)$ between rainfall amount treatments and small letters between dry interval treatments. L. chinensis withered during the 21-day interval (shadowed section) 
treatment for R-, and $188 \mathrm{~g} \mathrm{~m}^{-2}$ and $237 \mathrm{~g} \mathrm{~m}^{-2}$ for $\mathrm{R} 0$ and $\mathrm{R}+$, respectively, under the 18 days dry interval treatment (Fig. 1). Under the 21 days dry interval treatment, the aboveground parts of $L$. chinensis were withered after about 60 days of treatment (at late July) (Fig. 1 ). In addition, changes in the rainfall amount and dry interval also had significant interactive effects on biomass production (Table 1).

Changes in the rainfall amount and dry interval and their interaction had significant effects on the $\mathrm{S} / \mathrm{L}$ and $\mathrm{R} / \mathrm{S}$ of $L$. chinensis (Table 1). Increased amounts of rainfall and extended dry intervals significantly lowered S/L (Fig. 2a). Under prolonged dry intervals, the $\mathrm{R} / \mathrm{S}$ values produced a concave curve (Fig. 2b).

\section{Effects of rainfall treatments on plant height and ramet number}

Changes in the rainfall amount and dry interval had significant main effects on the plant height and ramet number (Table 1). Increases in the amount of rainfall led to a significant increase in plant height and ramet number except for the D21 treatment (Fig. 3a, b). With extension of the dry intervals, plant height and ramet number increased initially, but then decreased (Fig. 3a, b). For R-, peak values for plant height and ramet number were observed under the D15 treatment, with the maximum values reached for $\mathrm{R} 0$ and $\mathrm{R}+$ with the $\mathrm{D} 18$ treatment (Fig. 3a, b). Changes in the amount of rainfall amount and the dry interval also had significant interactive effects on plant height (Table 1).

\section{Effects of rainfall treatments on soil properties}

Changes in the amount of rainfall, the length of dry intervals, and their interaction had significant effects on mean soil water content (MSWC) (Table 1). Increased rainfall amounts resulted in significant increases in the MSWC (Fig. 4a, b, c). With prolonged dry intervals, the MSWC first increased and then decreased (Fig. 4a, b, c). The maximum MSWC values were observed in the D18 treatment, reaching $11.3\left(\% \mathrm{v} \mathrm{v}^{-1}\right), 13.7\left(\% \mathrm{v} \mathrm{v}^{-1}\right)$, and $16.3\left(\% \mathrm{v} \mathrm{v}^{-1}\right)$ for R-, R0, and R+, respectively (Fig. 4a).

Regarding available soil nutrients, changes in the rainfall amount and the dry interval length had significant main effects on the available soil $\mathrm{NH}_{4}{ }^{+}-\mathrm{N}, \mathrm{NO}_{3}{ }^{-}-\mathrm{N}$, and $\mathrm{P}$ (Table 1). Elevated rainfall decreased the available soil $\mathrm{NH}_{4}{ }^{+}-\mathrm{N}, \mathrm{NO}_{3}{ }^{-}-\mathrm{N}$, and $\mathrm{P}$ (Table 1, Fig. 5a, b), but with prolonged dry intervals the trend was an initial reduction and then a rise (Fig. 5a, b). Minimum values of available soil $\mathrm{N}$ and $\mathrm{P}$ were observed under the D18 treatment for R-, R0, and R+ (Fig. 5a, b). Furthermore, changes in the rainfall amounts and dry intervals also had significant interactive effects on $\mathrm{NO}_{3}{ }^{-}-\mathrm{N}$ (Table 1).

\section{The response mechanism of plant biomass production to variation in rainfall patterns}

Before undertaking PLS-PM (partial least squares path modeling) analysis, a stepwise regression method was used to determine the relative importance of environmental factors (rainfall amounts, dry intervals, available soil $\mathrm{NH}_{4}{ }^{+}-\mathrm{N}, \mathrm{NO}_{3}{ }^{-}-\mathrm{N}, \mathrm{P}$, and $\mathrm{MSWC}$ ) in explaining plant biomass. We found that dry intervals, MSWC, and soil $\mathrm{NO}_{3}{ }^{-}-\mathrm{N}$ significantly influenced plant biomass. The subsequent PLS-PM illustrated the direct and indirect relationships of plant biomass production to dry intervals, MSWC, and $\mathrm{NO}_{3}{ }^{-}-\mathrm{N}$. The dry intervals showed a direct negative (effect size -0.24 ) relationship to biomass production. Dry intervals can also influence biomass production by altering MSWC (effect size 0.76)

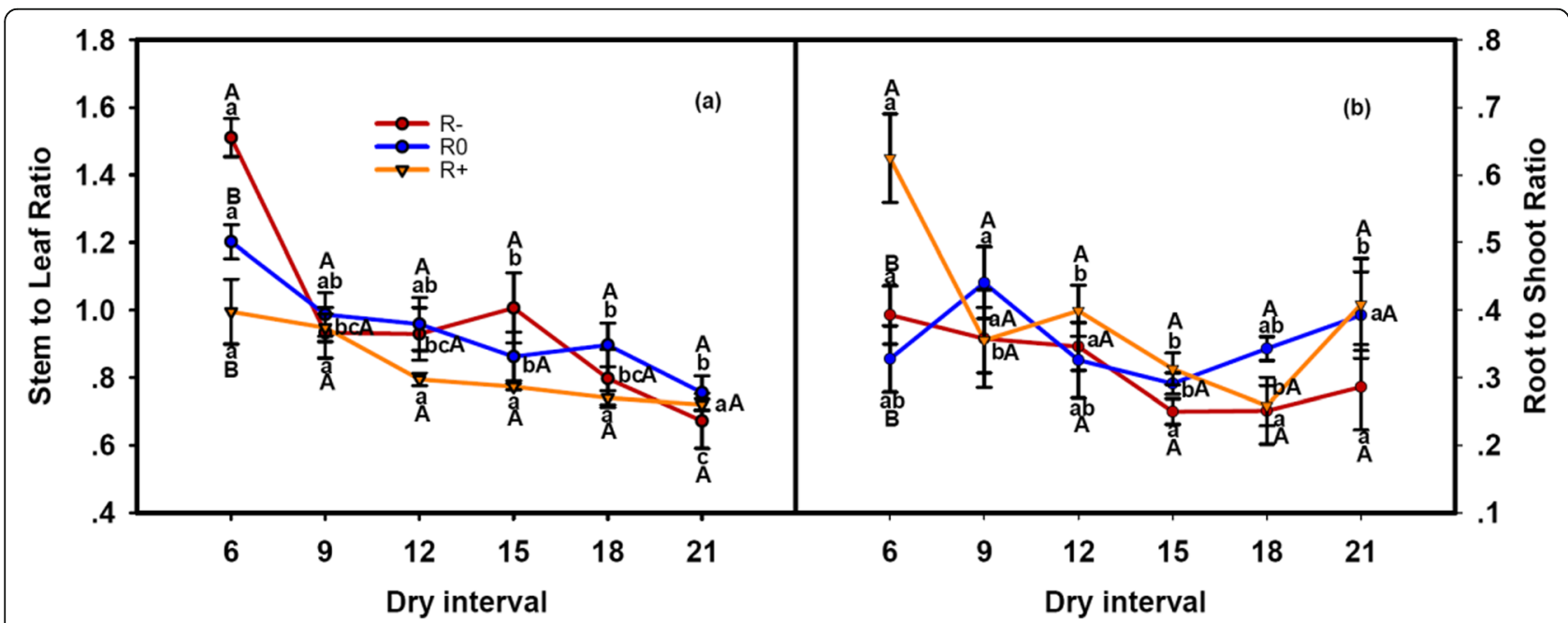

Fig. 2 Responses of (a) the ratio of stem to leaf and (b) the ratio of root to shoot to the variation in rainfall amounts and dry intervals. The values at each dry interval are the means \pm SE $(n=4)$. Capital letters indicate significant differences $(p<0.05)$ between rainfall amount treatments and small letters between dry interval treatments 


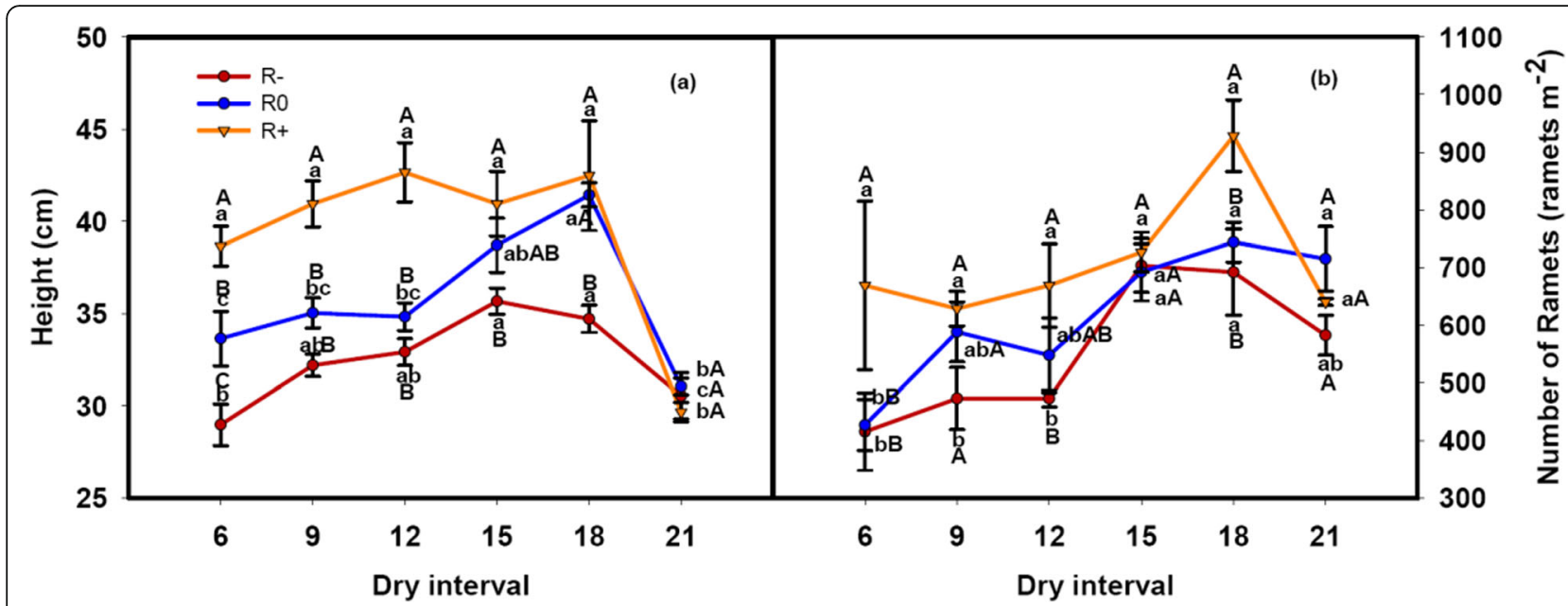

Fig. 3 Responses of (a) plant height and (b) ramets number to the variation in rainfall amounts and dry intervals. The values at each dry interval are the means \pm SE $(n=4)$. Capital letters indicate significant differences $(p<0.05)$ between rainfall amount treatments and small letters between dry interval treatments

and $\mathrm{NO}_{3}{ }^{-} \mathrm{-N}$ (effect size -0.29 ). The MSWC exhibited a positive effect on plant biomass (effect size 0.33), and a negative effect on $\mathrm{NO}_{3}{ }^{-}-\mathrm{N}$ (effect size -0.9 ). $\mathrm{NO}_{3}{ }^{-} \mathrm{N}$ showed a negative relationship to biomass production (effect size - 0.58) (Fig. 6).

\section{Discussion}

Except for the 21-day interval treatment, the plant aboveground biomass and belowground biomass increased notably with increasing amounts of rainfall, irrespective of either short or long dry-interval treatments (Fig. 1). In fact, it has been established previously that elevated amounts of rainfall can alleviate drought in arid and semi-arid ecosystems $[29,30]$. The reason for the positive correlation between biomass production and moderately prolonged dry intervals between rainfall events is likely due to an increase in soil moisture at depths where evaporative demand is negligible (deep in the $0-10 \mathrm{~cm}$ profile), and this would contrast with situations where small amounts of precipitation of water deeper into the profile [15] (Fig. 4). Indeed, the fine roots of L. chinensis were located in the $0-10 \mathrm{~cm}$ soil profile, and so the plant can utilize both shallow and deeper soil moisture resources [31]. The plant water status under different rainfall patterns also supported the results of aboveground biomass changing (Fig. S2). The plant aboveground parts withered in the late-July, the net photosynthetic rate and transpiration rate were zero. After rewatering on 2nd Aug, the new ramets were germination from the underground bud. The new leaves had high photosynthetic rate and transpiration rate, so the average photosynthetic rate and transpiration rate in 21-day dry interval were no significant different even higher than 6-day dry interval (Fig. S2 a and b).

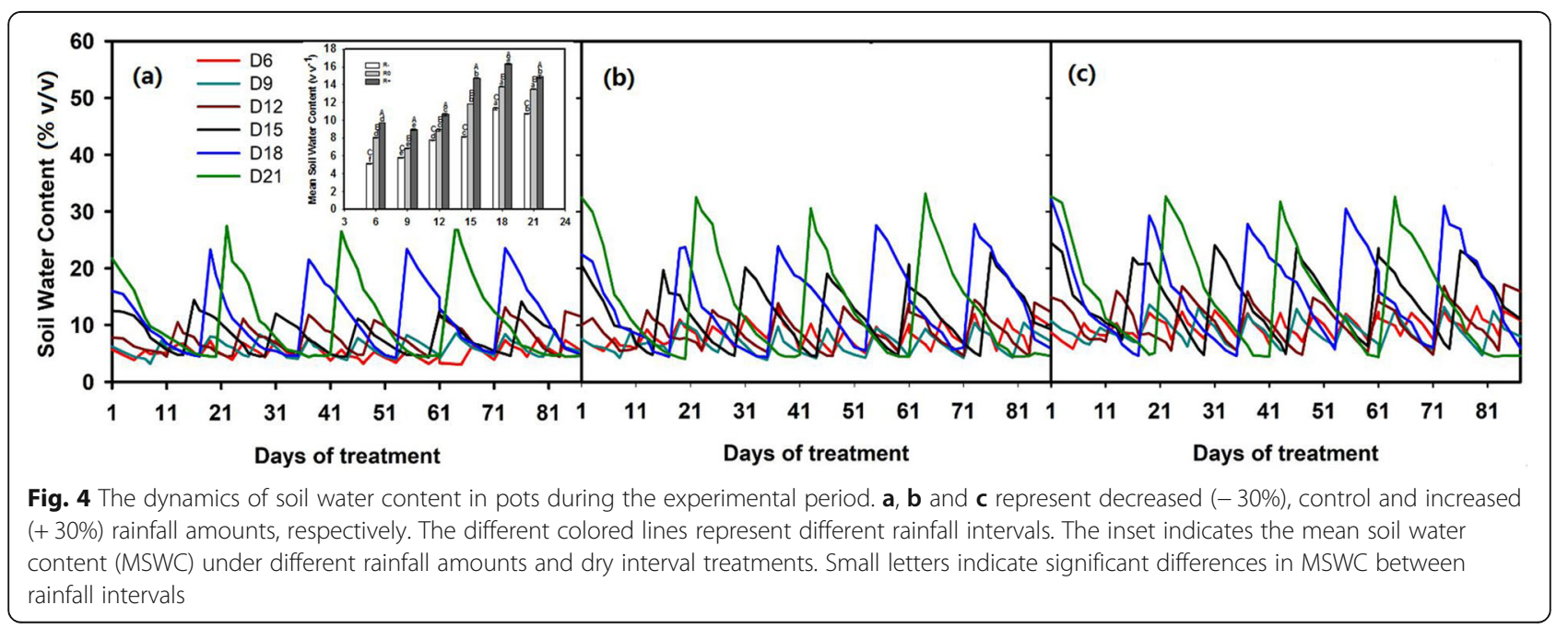




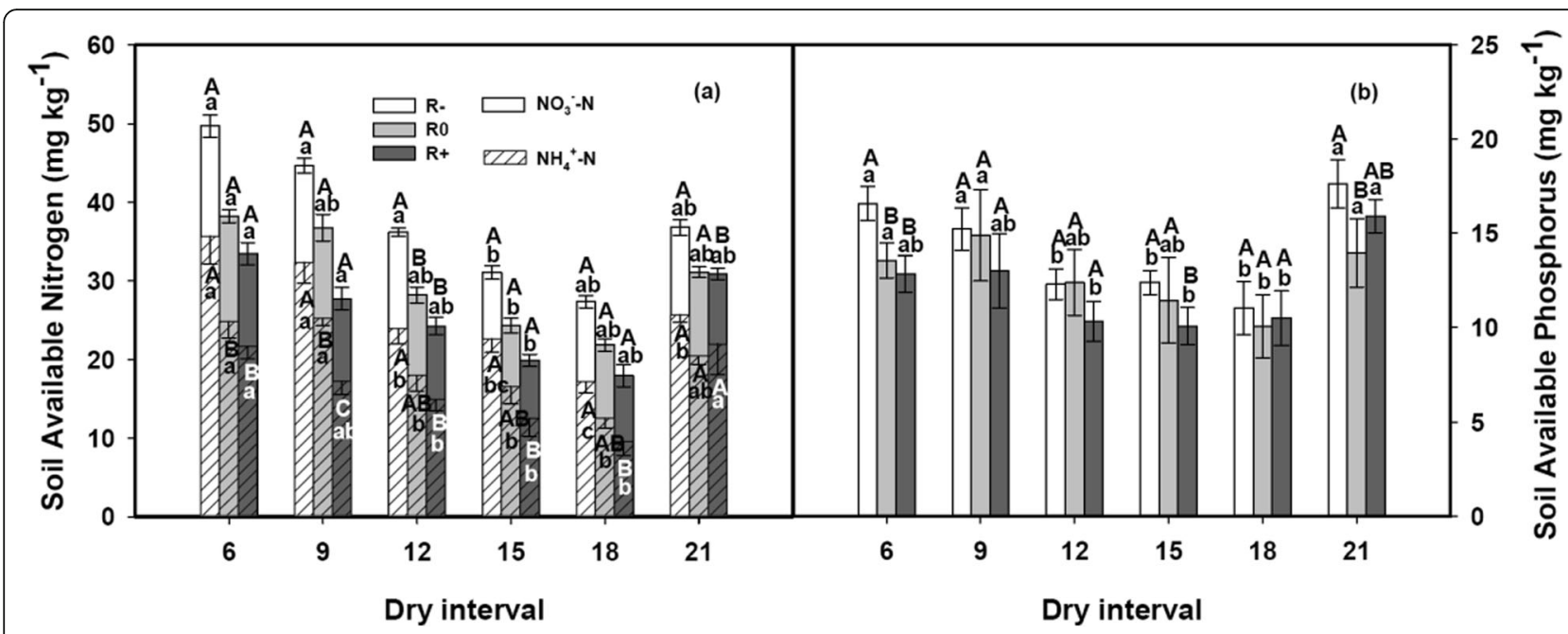

Fig. 5 Responses of (a) soil nitrate nitrogen content $\left(\mathrm{NO}^{-}-\mathrm{N}\right)$ and soil ammonium nitrogen content $\left(\mathrm{NH}^{-}{ }^{+}{ }^{-} \mathrm{N}\right)$, and $(\mathbf{b})$ available soil phosphorus to the variation in rainfall amounts and dry intervals. The values at each dry interval are the means $\pm \operatorname{SE}(n=4)$. Capital letters indicate significant differences $(p<0.05)$ between rainfall amount treatments and small letters between dry interval treatments

However, the green leaves to total leaves ratio reached the minimum value in 21-day interval treatment (Fig. S2 d). This result is partly similar to the study conducted in perennial Bouteloua gracilis grassland where fewer but larger rainfall events produced the highest value of aboveground biomass in northeastern Colorado [15]. It also supports our first hypothesis that prolonged dry intervals combined with large rainfall events can improve plant productivity in semi-arid grassland. However, our result is inconsistent with research on the effects of dry intervals on the growth of Agriophyllum squarrosum in the Mu Us Desert [29]. Firstly, this could be due to the

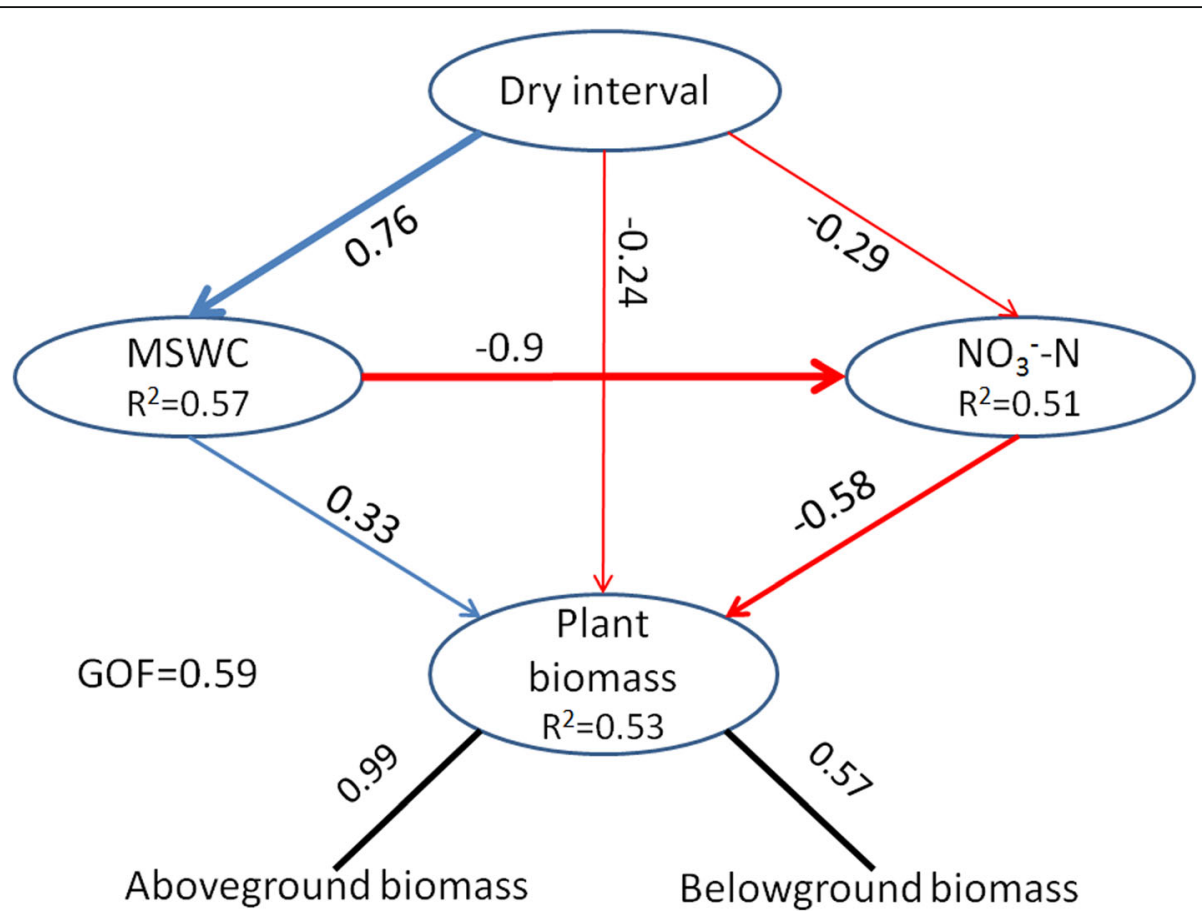

Fig. 6 The direct and indirect effects of dry interval, mean soil water content and soil NO3-N on plant biomass were determined by partial least squares path modeling. Observed variables are represented in the ellipses. The loadings (the correlations between observed variables) are indicated as the values near the arrowed line, and the path coefficients (between observed variables) and the coefficients of determination ( $R^{2}$ in ellipses) were calculated after 999 bootstraps. The model was assessed using the goodness of fit (GOF) statistic, a measure of the overall prediction performance. The GOF was 0.59 
soil texture in the Mu Us Desert is sandy and characterized by lower water-holding capacity [29]. However, the soil in our study site is clay loam, which has higher water-holding capacity than sandy soil [32]. Secondly, $A$. squarrosum is an annual forb, has a different response to soil moisture circumstance $[15,29]$. Thus, it suggests that the response of vegetation to rainfall pattern varies with soil types and species changes [33].

Under low rainfall amount combined with more frequent rainfall events, L. chinensis aboveground biomass reduced due to smaller plant size and lower ramet numbers (Fig. 1, Fig. 3). Meanwhile, higher values for the S/L and R/S ratios were observed (Fig. 2). These results indicate that $L$. chinensis can adopt drought avoidance strategies to minimize water loss and maintain plant tissue hydration during such rain patterns. However, if the dry interval is too long and exceeds the plant's drought duration tolerance, aboveground parts of the plant may wither (Fig. 1, Fig. 3). The mechanisms for this phenomenon include loss of antioxidant defenses in chloroplasts, and accelerating senescence in aboveground tissues to protect the belowground buds from water loss [34, 35]. Plants can resist and survive drought through different adaptive strategies, but there will be a decline in plant productivity. This result confirmed the second hypothesis that once the interval between precipitation events exceeds the soil moisture recharge interval, plant growth ceases.

Previous studies have shown that the amount of annual rainfall only partially explains differences in grassland productivity [36]. The length of the intervals between rainfall events and the intensity of the precipitation can also be identified as important regulators of plant growth [37]. In our study, we found that dry intervals can influence plant biomass production by altering the MSWC and available soil nitrogen (Fig. 6). In addition, the available soil nitrogen content decreased following prolonged the intervals between rainfall events (Fig. 5). It is possible that prolonged dry intervals combined with large rainfall events for a given amount of rainfall can increase soil moisture content, and then enhance the solubility of available soil nutrients. Then, the soil available nutrient could be more easily absorbed by plants [20]. Furthermore, increases in rainfall intensity per event can lead to leaching of available nitrogen into deeper soil layers [18], and high water content also can increase denitrification rates by displacing oxygen and creating anoxic conditions in the soil, which then stimulate anaerobic reduction of nitrate to $\mathrm{N}_{2}$ and $\mathrm{N}_{2} \mathrm{O}$ [21]. It is suggested that increasing frequencies of heavy precipitation events due to climate change may accelerate the loss of available soil nitrogen in semi-arid grassland ecosystems in the future.

\section{Conclusions}

Our results indicate that: 1) for certain combinations of prolonged dry intervals and intervening high rainfall events, semi-arid grassland productivity might be improved, but these conditions may lead to nitrogen limitation via leaching and plant absorption. 2) Under extremely prolonged dry intervals, even though the mean soil water content may be high, when the length of the dry period exceeds the soil moisture recharge interval, plant growth ceases. The yield of $L$. chinensis directly affects the livestock production and local economy of Eurasian grassland. Meanwhile, L. chinensis is a typical perennial rhizomatous grass, the response of $L$. chinensis to the rainfall pattern variation can also reflect the response of other perennial grass, at least rhizomatous grass, to the rainfall pattern changes. These results imply that moderately prolonged dry intervals with intervening large precipitation events can promote semiarid grassland productivity, but extremely prolonged dry intervals restrict production. This study highlights the crucial role that altered patterns of precipitation could have on grassland productivity in semi-arid ecosystems.

\section{Methods}

\section{Study site and plant material}

This experiment was conducted at the central Songnen grassland (Songnen Grassland Ecological Research Station of Northeast Normal University, Changling County in Jilin Province, China, $44^{\circ} 45^{\prime} \mathrm{N}, 123^{\circ} 45^{\prime} \mathrm{E}$ ), located on the Eastern Eurasian Steppe. This part of grassland belongs to the experimental land of the Northeast Normal University for the research of grassland science, and the university allows us to experiment here. This area has a typical mesothermal monsoon climate with dry and cold winters and relatively wet and warm summers [32, 38]. Annual mean temperature ranges from $4.6{ }^{\circ} \mathrm{C}$ to $6.4{ }^{\circ} \mathrm{C}$ and annual precipitation ranges from 280 to $400 \mathrm{~mm}$ with about $80 \%$ of precipitation events having occurred during the period from June to August in the past 50 years (1961-2010). The mono-dominated species is Leymus. chinensis (Trin.) Tzvel. (Herbarium of Northwest A \& F University (WUK, 0442655)) in this study area. $L$. chinensis is a perennial clonal plant with vigorous belowground rhizomes. It mainly relies on vegetative propagation for population renewal and has high palatability for livestock such as cattle and sheep [39]. Therefore, to predict the production of $L$. chinensis, it is necessary to understand the influence of rainfall variation on its growth in this area.

\section{Experiment design and field manipulation}

We used a two-factor randomized complete block design to manipulate the amounts of precipitation and dry intervals between precipitation events from June to August 
2018. According to historical rainfall data at the local site (data from Changling County Meteorological Bureau), three levels of controlled precipitation were used. The long-term average biologically effective precipitation during the period from June 1st to September 1st was $334 \mathrm{~mm}$ (R0), and a 30\% decrease and a 30\% increase relative to the long-term average biologically effective rainfall of $233 \mathrm{~mm}$ and $434 \mathrm{~mm}$ ( $\mathrm{R}$ - and $\mathrm{R}+$ ), respectively, were also used. Events with daily precipitation greater than or equal to $2 \mathrm{~mm}$ were regarded as biologically effective events [15]. Meanwhile, cases of more than three days of consecutive precipitation were divided into two events [15]. At this site, the dry intervals between rainfall events ranged from 8.6 days to 13.3 days. Based on IPCC predictions that the dry intervals between rainfall events will be prolonged in the future [9], we selected six levels of dry intervals; six days, nine days, twelve days, fifteen days, eighteen days, and twenty-one days.

To determine rainfall amounts and intervals more accurately, we conducted a simulated rainfall experiment under an arched rainout shelter with steel frames and clear polyethylene roofs (the length and width of the shelter were $6.5 \mathrm{~m}$ and $4.5 \mathrm{~m}$, respectively). On May 15, 2018, Professor Chunsheng $\mathrm{Mu}$ undertook the formal identification of the plant material and chose a patch of homogeneous $L$. chinensis grassland for experiment. We removed the litter, then dug out plant-soil cores (each $24 \mathrm{~cm}$ in diameter and $25 \mathrm{~cm}$ in depth) from the homogeneous $L$. chinensis grassland. There were $18(3 \times 6)$ treatments with four replicates each, totaling $72(18 \times 4)$ plant-soil cores for this study. After being dug out carefully, each of the plant-soil cores was transferred to a plastic pot $(24 \mathrm{~cm}$ diameter and $26 \mathrm{~cm}$ height). The rooting system of $L$. chinensis is mainly distributed within the $0-10 \mathrm{~cm}$ soil depth, so the height of the pot is sufficient for plant root growth [31, 40]. Before the experiment, plants were allowed to acclimatize to their pots for 15 days, and were watered adequately every three days (a total of five times) to ensure survival and even growth (about $11.4 \pm 1.3 \mathrm{~cm}$ high for plant in each pot), and the values of soil water content (measured with a TRIME Pico64 (IMKO. GmbH. Ettlingen. Germany)) were similar in each pot $\left(6.03 \pm 0.52 \% \mathrm{v} \mathrm{v}^{-1}\right)$. The volume of experimental water was quantified with a measuring cylinder, and we used a watering can to simulate natural precipitation, with watering occurring between 6 : 30 and 9:30 AM (for detailed information about the intensity and intervals of the rainfall events see Table 2).

In our experiment, the arrangement of pots is shown in Fig. S1. The pots were placed $0.75 \mathrm{~m}$ away from the edge of shelter to prevent exposure from ambient rainfall. The aisles between the treatments were $0.5 \mathrm{~m}$. The distance between pots in a row was $0.13 \mathrm{~m}$. Final harvest

Table 2 The detailed date and intensity for each rainfall event. The frequencies for the 6-day, 9-day, 12-day, 15-day, 18-day and 21day rainfall intervals were $15,10,8,6,5$ and 4, respectively. The total rainfall amounts for the R-, R0 and R+ treatments were 233 mm, $334 \mathrm{~mm}$ and $434 \mathrm{~mm}$, respectively

\begin{tabular}{|c|c|c|c|c|c|c|c|c|c|c|c|c|c|c|c|c|c|c|c|c|c|c|c|c|}
\hline & & $5 / 31$ & $6 / 6$ & $6 / 9$ & $\begin{array}{l}6 / \\
12\end{array}$ & $\begin{array}{l}6 / \\
15\end{array}$ & $\begin{array}{l}6 / \\
18\end{array}$ & $6 / 21$ & $\begin{array}{l}6 / \\
24\end{array}$ & $\begin{array}{l}6 / \\
27\end{array}$ & $\begin{array}{l}6 / \\
30\end{array}$ & $7 / 6$ & $7 / 12$ & $\begin{array}{l}7 / \\
15\end{array}$ & $\begin{array}{l}7 / \\
18\end{array}$ & $\begin{array}{l}7 / \\
24\end{array}$ & $\begin{array}{l}7 / \\
30\end{array}$ & $8 / 2$ & $8 / 5$ & $\begin{array}{l}8 / \\
11\end{array}$ & $\begin{array}{l}8 / \\
14\end{array}$ & $\begin{array}{l}8 / \\
17\end{array}$ & $\begin{array}{l}8 / \\
20\end{array}$ & $\begin{array}{l}8 / \\
23\end{array}$ \\
\hline \multirow[t]{6}{*}{ R- } & D6 & 15.5 & 15.5 & 1 & 15.5 & 1 & 15.5 & 1 & 15.5 & 1 & 15.5 & 15.5 & 15.5 & 1 & 15.5 & 15.5 & 15.5 & 1 & 15.5 & 15.5 & 1 & 15.5 & 1 & 15.5 \\
\hline & D9 & 23.3 & 1 & 23.3 & 1 & $\backslash$ & 23.3 & 1 & 1 & 23.3 & 1 & 23.3 & $\backslash$ & 23.3 & 1 & 23.3 & 1 & 23.3 & 1 & 23.3 & 1 & 1 & 23.3 & 1 \\
\hline & D12 & 33.3 & 1 & 1 & 33.3 & 1 & 1 & 1 & 33.3 & 1 & 1 & 33.3 & 1 & 1 & 33.3 & 1 & 33.3 & 1 & 1 & 33.3 & 1 & 1 & 1 & 33.3 \\
\hline & D15 & 38.9 & 1 & 1 & $\backslash$ & 38.9 & 1 & 1 & 1 & 1 & 38.9 & 1 & 1 & 38.9 & $\backslash$ & 1 & 38.9 & $\backslash$ & 1 & 1 & 38.9 & 1 & 1 & 1 \\
\hline & D18 & 46.7 & 1 & 1 & 1 & 1 & 46.7 & 1 & 1 & 1 & 1 & 46.7 & 1 & 1 & 1 & 46.7 & 1 & 1 & 1 & 46.7 & 1 & 1 & 1 & 1 \\
\hline & D21 & 58.4 & 1 & 1 & 1 & 1 & 1 & 58.4 & 1 & 1 & 1 & 1 & 58.4 & 1 & 1 & 1 & 1 & 58.4 & 1 & $\backslash$ & 1 & 1 & 1 & 1 \\
\hline \multirow[t]{6}{*}{ Ro } & D6 & 22.2 & 22.2 & 1 & 22.2 & $\backslash$ & 22.2 & 1 & 22.2 & 1 & 22.2 & 22.2 & 22.2 & 1 & 22.2 & 22.2 & 22.2 & 1 & 22.2 & 22.2 & 1 & 22.2 & 1 & 22.2 \\
\hline & D9 & 33.3 & 1 & 33.3 & 1 & $\backslash$ & 33.3 & 1 & 1 & 33.3 & 1 & 33.3 & 1 & 33.3 & 1 & 33.3 & $\backslash$ & 33.3 & 1 & 33.3 & 1 & 1 & 33.3 & 1 \\
\hline & D12 & 47.6 & $\backslash$ & 1 & 47.6 & 1 & 1 & $\backslash$ & 47.6 & 1 & 1 & 47.6 & $\backslash$ & 1 & 47.6 & 1 & 47.6 & 1 & $\backslash$ & 47.6 & 1 & 1 & 1 & 47.6 \\
\hline & D15 & 55.6 & 1 & 1 & 1 & 55.6 & 1 & $\backslash$ & 1 & 1 & 55.6 & 1 & $\backslash$ & 55.6 & 1 & 1 & 55.6 & 1 & 1 & $\backslash$ & 55.6 & 1 & 1 & 1 \\
\hline & D18 & 66.7 & 1 & 1 & 1 & 1 & 66.7 & 1 & 1 & $\backslash$ & 1 & 66.7 & $\backslash$ & 1 & 1 & 66.7 & 1 & 1 & 1 & 66.7 & 1 & 1 & 1 & 1 \\
\hline & D21 & 83.4 & 1 & 1 & 1 & 1 & 1 & 83.4 & 1 & 1 & 1 & 1 & 83.4 & 1 & 1 & 1 & $\backslash$ & 83.4 & $\backslash$ & 1 & 1 & 1 & 1 & 1 \\
\hline \multirow[t]{6}{*}{$\mathrm{R}+$} & D6 & 28.9 & 28.9 & 1 & 28.9 & 1 & 28.9 & 1 & 28.9 & $\backslash$ & 28.9 & 28.9 & 28.9 & 1 & 28.9 & 28.9 & 28.9 & 1 & 28.9 & 28.9 & 1 & 28.9 & 1 & 28.9 \\
\hline & D9 & 43.3 & 1 & 43.3 & 1 & 1 & 43.3 & 1 & 1 & 43.3 & 1 & 43.3 & 1 & 43.3 & $\backslash$ & 43.3 & 1 & 43.3 & 1 & 43.3 & 1 & 1 & 43.3 & 1 \\
\hline & D12 & 61.9 & $\backslash$ & 1 & 61.9 & $\backslash$ & $\backslash$ & $\backslash$ & 61.9 & $\backslash$ & 1 & 61.9 & 1 & 1 & 61.9 & 1 & 61.9 & $\backslash$ & 1 & 61.9 & 1 & 1 & 1 & 61.9 \\
\hline & D15 & 72.3 & $\backslash$ & 1 & 1 & 72.3 & 1 & 1 & 1 & 1 & 72.3 & 1 & 1 & 72.3 & 1 & 1 & 72.3 & 1 & 1 & $\backslash$ & 72.3 & 1 & 1 & 1 \\
\hline & D18 & 86.7 & 1 & 1 & $\backslash$ & $\backslash$ & 86.7 & 1 & 1 & $\backslash$ & 1 & 86.7 & $\backslash$ & 1 & $\backslash$ & 86.7 & 1 & $\backslash$ & 1 & 86.7 & 1 & $\backslash$ & 1 & 1 \\
\hline & D21 & 108.4 & 1 & $\backslash$ & $\backslash$ & $\backslash$ & 1 & 108.4 & 1 & 1 & 1 & 1 & 108.4 & 1 & 1 & 1 & 1 & 108.4 & 1 & 1 & 1 & 1 & 1 & 1 \\
\hline
\end{tabular}


was on the 26th of August 2018, and the time elapsed from the start was 87 days. To simulate natural conditions, 72 pots were buried into the soil with the upper edge $1 \mathrm{~cm}$ above soil surface. The shelter's roof was only used during rain events, so once the weather turned clear we removed the polyethylene roof immediately. Each pot had a $1.5-\mathrm{cm}$ diameter hole in the bottom to allow for drainage [28].

\section{Soil properties}

For each pot, the soil volume water content at the depth of $10 \mathrm{~cm}$ was measured with a TRIME Pico64 (IMKO. GmbH. Ettlingen. Germany) field moisture TDR-sensor between 16:00-17:00 pm every one to two days. The mean soil water content (MSWC) was calculated as the averaged value of soil water content during the experiment. At the end of the treatment, three soil cores (diameter $2 \mathrm{~cm}$, depth $25 \mathrm{~cm}$ ) were taken from each pot (carefully removing the plant material) and were mixed in sealed bags to form one composite sample. The soil samples were kept in a cooler during transport to the laboratory where they were carefully homogenized and sieved through $2 \mathrm{~mm}$ mesh. Each sample was separated into two parts after the removal of roots. One part was kept at $-20^{\circ} \mathrm{C}$ to measure soil ammonium nitrogen content $\left(\mathrm{NH}_{4}{ }^{+}-\mathrm{N}\right)$ and nitrate nitrogen content $\left(\mathrm{NO}_{3}{ }^{-}-\mathrm{N}\right)$. The remainder was used to measure the available $\mathrm{P}$ concentration after being air-dried for 15-days. The concentrations of soil $\mathrm{NH}_{4}^{+}-\mathrm{N}$ and $\mathrm{NO}_{3}{ }^{-}-\mathrm{N}$ were determined using a continuous flow analyzer (Alliance Flow Analyzer, Futura, Frépillon, France). Soil available P was determined via the molybdate blue colorimetric method following extraction with $0.5 \mathrm{~mol} \mathrm{~L}^{-1} \mathrm{NaHCO}_{3}$.

\section{Plant performance}

Three plants of per pot were randomly marked to measure the photosynthetic index. The plant net photosynthetic rate $(\mathrm{A})$, transpiration rate $(\mathrm{E})$, water use efficiency (WUE) were measured with an open gasexchange system (PPsystem, CIRAS-3, Hasha Scientific Instruments Limited, USA). In order to reduce the experiment error, the photosynthetic indexes were measured on the day before and after watering respectively between 1st Aug to 15th Aug. The average of the two measurements represents the actual photosynthetic index. Meanwhile, we observed and recorded the green leaves to total leaves ratio per pot on the 25th of August 2018.

We collected the above- and below-ground parts (washed free of soil) of plants for each pot at the end of the experiment. Individual plant heights were measured and the number of ramets was counted for every pot. Belowground parts were gently washed of soil and collected with a $1 \mathrm{~mm}$ mesh sieve. The plant leaves, stems, and belowground parts of each pot were detached and weighed separately after drying at $65^{\circ} \mathrm{C}$ for $48 \mathrm{~h}$. Aboveground biomass was calculated as the sum of the dry masses of leaves and stems. Biomass allocation explained how plants allocate their biomass to different organs [41]. The Stem/Leaf ratio $(\mathrm{S} / \mathrm{L})$ was determined as the ratio of stem dry biomass to leaf dry biomass, which can be calculated with the following equation [41]:

$$
\mathrm{S} / \mathrm{L}=\frac{\text { Stem dry mass }\left(\mathrm{g} \mathrm{m}^{-2}\right)}{\text { Leaf dry mass }\left(\mathrm{g} \mathrm{m}^{-2}\right)}
$$

The Root/Shoot ratio $(\mathrm{R} / \mathrm{S})$ can be calculated with the following equation [41]:

$$
\mathrm{R} / \mathrm{S}=\frac{\text { Belowground dry mass }\left(\mathrm{g} \mathrm{m}^{-2}\right)}{\text { Aboveground dry mass }\left(\mathrm{g} \mathrm{m}^{-2}\right)}
$$

\section{Statistical analysis}

We used two-way ANOVAs to assess the effects of rainfall amounts and intervals and their interaction with soil properties (soil available $\mathrm{P}$ content, $\mathrm{NH}_{4}{ }^{+}-\mathrm{N}$ content, $\mathrm{NO}_{3}{ }^{-} \mathrm{N}$ content, and MSWC) and vegetation performance (plant height, number of ramets, aboveground biomass, belowground biomass, $\mathrm{S} / \mathrm{L}$, and R/S). Differences between treatments were compared by Duncan's multiple range tests. The above analyses were performed using SPSS 21.0 statistical software (SPSS Institute, Cary, NC, U.S.A.). Partial least squares path modeling (PLS$\mathrm{PM}$, using the inner plot function in the R plspm package) was used to further identify the possible pathways by environment factors to control for L. chinensis biomass accumulation. Before PLS-PM, the stepwise regression method was used to determine the relative importance of environmental factors (rainfall amount, dry interval, $\mathrm{NH}_{4}{ }^{+}-\mathrm{N}, \mathrm{NO}_{3}{ }^{-}-\mathrm{N}$, soil available $\mathrm{P}$, and MSWC) in explaining plant biomass.

\begin{abstract}
Abbreviations
RO: The long-term average biologically effective rainfall amount during the period from June 1st to September 1st; $\mathrm{R}+$ : a $30 \%$ increase relative to the long-term average biologically effective rainfall amount during the period from June 1st to September 1st; R-: a 30\% decrease relative to the long-term average biologically effective rainfall amount during the period from June 1st to September 1st; D6: Six days dry intervals between rainfall events; D9: Nine days dry intervals between rainfall events; D12: Twelve days dry intervals between rainfall events; D15: Fifteen days dry intervals between rainfall events; D18: Eighteen days dry intervals between rainfall events; D21: Twenty-one days dry intervals between rainfall events; MSWC: The mean soil water content; $\mathrm{NH}_{4}{ }^{+}-\mathrm{N}$ : Soil ammonium nitrogen content; $\mathrm{NO}_{3}{ }^{-}-\mathrm{N}$ : Soil nitrate nitrogen content; P: Phosphorus; S/L: The Stem/Leaf ratio; R/S: The Root/ Shoot ratio; PLS-PM: Partial least squares path modeling
\end{abstract}

\section{Supplementary Information}

The online version contains supplementary material available at https://doi. org/10.1186/s12870-021-02920-y.

Additional file 1. 


\section{Acknowledgements}

We would like to express our sincere thanks to Jiayu Han, Xiaowei Wei, Ming Yan and Ming LV for their help during the field and laboratory work.

\section{Authors' contributions}

JZ collected field data, performed data analysis, and drafted the manuscript. $\mathrm{JZ}, \mathrm{XS}$ and $\mathrm{CM}$ conceived and designed the research, and revised the manuscript. JW revised and wrote the manuscript. BM, YS, YY, and XW coordinated the study and helped review the manuscript. [CM]1 corresponding to [Chunsheng Mu], and [JW]1 corresponding to [Junfeng Wang]. All authors read and approved the final manuscript.

\section{Funding}

The study was funded by the National Basic Research Program of China (2016YFC0500705), the National Natural Science Foundation of China (31971505; 41971065), the Natural Science Foundation of Jilin Province (YDZJ202101ZYTS081), the Youth Innovation Promotion Association, Chinese Academy of Sciences (2019235), and the Fundamental Research Funds for the Central Universities (2412020QD022). The design of the study and field data collection were supported by the National Basic Research Program of China (2016YFC0500705), the National Natural Science Foundation of China (31971505; 41971065), and the Natural Science Foundation of Jilin Province (YDZJ202101ZYTS081). The analysis and interpretation of data were supported by the Youth Innovation Promotion Association, Chinese Academy of Sciences (2019235). Transportation expenses and writing the manuscript were paid by the Fundamental Research Funds for the Central Universities (2412020QD022)

\section{Availability of data and materials}

The dataset supporting the conclusions of this article is included within the supplementary file (Electronic supplementary material-data.xlsx). It is available from the corresponding author on reasonable request.

\section{Declarations}

\section{Ethics approval and consent to participate}

Not applicable.

\section{Consent for publication}

Not applicable.

\section{Competing interests}

The authors declare that they have no competing interests.

\section{Author details}

${ }^{1}$ Key Laboratory of Vegetation Ecology, Ministry of Education, Institute of Grassland Science, School of Life Sciences, Northeast Normal University, Changchun 130024, P.R. China. ${ }^{2}$ Northeast Institute of Geography and Agroecology, Chinese Academy of Sciences, Changchun 130102, P.R. China. ${ }^{3}$ School of Life Sciences, Northeast Normal University, Changchun 130024, P.R. China.

\section{Received: 25 September 2020 Accepted: 8 March 2021} Published online: 20 March 2021

\section{References}

1. Huxman TE, Smith MD, Fay PA, Knapp AK, Shaw MR, Loik ME, Smith SD, Tissue DT, Zak JC, Weltzin JF, Pockman WT, Sala OE, Haddad BM, Harte J, Koch GW, Schwinning S, Small EE, Williams DG. Convergence across biomes to a common rain-use efficiency. Nature. 2004;429(6992):651-4. https://doi. org/10.1038/nature02561.

2. Beier C, Beierkuhnlein C, Wohlgemuth T, Penuelas J, Emmett B, Körner C, Boeck HD, Christensen JH, Leuzinger S, Janssens IA, Hansen K. Precipitation manipulation experiments-challenges and recommendations for the future. Ecol Lett. 2012;15(8):899-911. https://doi.org/10.1111/j.1461-0248.2012.01 793.x

3. Huntington TG. Evidence for intensification of the global water cycle: review and synthesis. J Hydrol. 2006;319(1-4):83-95. https://doi.org/10.1016/j. jhydrol.2005.07.003.

4. Bai YF, Wu JG, Xing Q, Pan QM, Huang JH, Yang DL, Han XG. Primary production and rain use efficiency across a precipitation gradient on the
Mongolia plateau. Ecology. 2008;89(8):2140-53. https://doi.org/10.1890/070992.1.

5. Swemmer AM, Knapp AK, Snyman HA. Intra-seasonal precipitation patterns and above-ground producitivity in three perennial grasslands. J Ecol. 2007; 95(4):780-8. https://doi.org/10.1111/j.1365-2745.2007.01237.x.

6. Liu YS, Pan QM, Zheng SX, Bai YF, Han XG. Intra-seasonal precipitation amount and pattern differentially affect primary production of two dominant species of Inner Mongolia grassland. Acta Oecol.-Int. J. Ecol. 2012; 44:2-10.

7. Guo Q, Hu ZM, Li SG, Li XR, Sun XM, Yu GR. Spatial variations in aboveground net primary productivity along a climate gradient in Eurasian temperate grassland: effects of mean annual precipitation and its seasonal distribution. Glob. Change Biol. 2012;18(12):3624-31. https://doi.org/10.1111/ gcb.12010.

8. Easterling DR. Climate extremes: observations, modeling, and impacts. Science. 2000;289(5487):2068-74. https://doi.org/10.1126/science.289.5487.2068.

9. IPCC. Climate change 2013: the physical science basis. Cambridge: Contribution of working group I to the fifth assessment report of the intergovernmental panel on climate change; 2013.

10. Thomey ML, Collins SL, Vargas R, Johnson JE, Brown RF, Natvig DO, Friggens MT. Effect of precipitation variability on net primary production and soil respiration in a chihuahuan desert grassland. Glob Change Biol. 2011;17(4): 1505-15. https://doi.org/10.1111/j.1365-2486.2010.02363.x.

11. Jobbágy EG, Sala OE. Controls of grass and shrub aboveground production in the Patagonian steppe. Ecol Appl. 2000;10(2):541-9. https://doi.org/10.1 890/1051-0761(2000)010[0541:COGASA]2.0.CO;2.

12. Reynolds JF, Kemp PR, Ogle K, Fernández RJ. Modifying the 'pulse reserve' paradigm for deserts of North America: precipitation pulses, soil water, and plant responses. Oecologia. 2004;141(2):194-210. https://doi.org/10.1007/ s00442-004-1524-4.

13. Robertson TR, Bell CW, Zak JC, Tissue DT. Precipitation timing and magnitude differentially affect aboveground annual net primary productivity in three perennial species in a chihuahuan desert grassland. New Phytol. 2008;181(1):230-42.

14. Knapp AK, Beier C, Briske DD, Classen AT, Luo YQ, Reichstein M, Smith MD, Smith SD, Bell JE, Fay PA, Heisler JL, Leavitt SW, Sherry R, Smith B, Weng ES. Consequences of more extreme precipitation regimes for terrestrial ecosystems. Bioscience. 2008:58(9):811-21. https://doi.org/10.1641/B580908.

15. Heisler-White $J$, Knapp AK, Kelly EF. Increasing precipitation event size increases aboveground net primary productivity in a semi-arid grassland. Oecologia. 2008;158(1):129-40. https://doi.org/10.1007/s00442-008-1116-9.

16. Jongen $M$, Unger $S$, Santos PJ. Effects of precipitation variability on carbon and water fluxes in the understorey of a nitrogen-limited montado ecosystem. Oecologia. 2014;176(4):1199-212. https://doi.org/10.1007/s00442014-3090-8.

17. Eskelinen A, Harrison S. Exotic plant invasions under enhanced rainfall are constrained by soil nutrients and competition. Ecology. 2014;95(3):682-92. https://doi.org/10.1890/13-0288.1.

18. Elrashidi MA, Mays MD, Fares A, Seybold C, Harder JL, Peaslee SD, VanNeste $P$. Loss of nitrate-nitrogen by runoff and leaching for agricultural watersheds. Soil Sci. 2005;170(12):969-84. https://doi.org/10.1097/01.ss.00001 87353.24364.a8

19. Walvoord MA. A reservoir of nitrate beneath desert soils. Science. 2003; 302(5647):1021-4. https://doi.org/10.1126/science.1086435.

20. Reichmann LG, Sala OE, Peters DPC. Water controls on nitrogen transformations and stocks in an arid ecosystem. Ecosphere. 2013;4(1):art11.

21. Wang $C H$, Wan SQ, Xing XR, Zhang L, Han XG. Temperature and soil moisture interactively affected soil net $n$ mineralization in temperate grassland in northern China. Soil Biol Biochem. 2006;38(5):1101-10. https:// doi.org/10.1016/j.soilbio.2005.09.009.

22. Zhang CC, Li XY, Wang Y, Wu HW, Wang P, Li W, Bai Y, Li EG, Wang S, Miao $C Y, W u X C$. Responses of two desert shrubs to simulated rainfall pulses in an arid environment, northwestern China. Plant Soil. 2019;435(1-2):239-55. https://doi.org/10.1007/s11104-018-3892-2.

23. Guo R, Zhou J, Zhong XL, Gu FX, Liu Q, Li HR. Effect of simulated warming on the functional traits of Leymus chinensis plant in Songnen grassland. AoB Plants. 2019;11:plz073.

24. Wang JF, Shi YJ, Ao YN, Yu DF, Wang J, Gao S, Knops JMH, Mu CS, Li ZJ. Summer drought decreases Leymus chinensis productivity through constraining the bud, tiller and shoot production. J Agron Crop Sci. 2019; 205(6):554-61. https://doi.org/10.1111/jac.12354. 
25. Ao YN, Wang JF, Liu MX, Wang J, Knops JMH, Mu CS. Larger seed size shows less germination and seedling growth decline caused by seed ageing under $\mathrm{Na}_{2} \mathrm{CO}_{3}$ stress in Leymus chinensis. Agron J. 2019;111(5):232631. https://doi.org/10.2134/agronj2018.12.0757.

26. Bai YF, Han XG, Wu JG, Chen ZZ, Li LH. Ecosystem stability and compensatory effects in the Inner Mongolia grassland. Nature. 2004; 431(7005):181-4. https://doi.org/10.1038/nature02850.

27. Bo T, Man J, Bai YF. Leaf nitrogen acquisition of Leymus chinensis varies with leaf age and land use change in a semiarid grassland. Environ Exp Bot. 2020;175:104051.

28. Zhang B, Zhu JJ, Pan QM, Liu YS, Chen SP, Chen DM, Yan Y, Dou SD, Han XG. Grassland species respond differently to altered precipitation amount and pattern. Environ Exp Bot. 2017;137:166-76. https://doi.org/10.1016/j. envexpbot.2017.02.006.

29. Gao RR, Yang XJ, Liu GF, Huang ZY, Walck JL. Effects of rainfall pattern on the growth and fecundity of a dominant dune annual in a semi-arid ecosystem. Plant Soil. 2015;389(1-2):335-47. https://doi.org/10.1007/s11104014-2366-4.

30. Ponce CGE, Moran MS, Huete A, Zhang Y, Bresloff C, Huxman TE. Ecosystem resilience despite large-scale altered hydroclimatic conditions. Nature. 2013; 494(7437):349-52. https://doi.org/10.1038/nature11836.

31. Meng B, Shi BK, Zhong SZ, Chai H, Li SX, Wang YB, Henry HAL, Ma JY, Sun $W$. Drought sensitivity of aboveground productivity in leymus chinensis meadow steppe depends on drought timing. Oecologia. 2019;191(3):68596. https://doi.org/10.1007/s00442-019-04506-w.

32. Shi YJ, Wang JF, Xavier LR, Mu CS, Knops JMH. Trade-offs and synergies between seed yield, forage yield, and $\mathrm{n}$-related disservices for a semi-arid perennial grassland under different nitrogen fertilization strategies. Biol Fert Soils. 2019;55(5):497-509. https://doi.org/10.1007/s00374-019-01367-6.

33. Fernandez-Illescas CP, Porporato A, Laio F, Rodriguez-Iturbe I. The ecohydrological role of soil texture in a water-limited ecosystem. Water Resour Res. 2001;37(12):2863-72. https://doi.org/10.1029/2000WR000121.

34. Munne-Bosch S, Jubany-Mari T, Alegre L. Drought-induced senescence is characterized by a loss of antioxidant defences in chloroplasts. Plant Cell Environ. 2001;24(12):1319-27. https://doi.org/10.1046/j.1365-3040.2001. 00794.x.

35. Zanne AE, Tank DC, Cornwell WK, Eastman JM, Smith SA, FitzJohn RG, McGlinn DJ, Meara BCO, Moles AT, Reich PB. Three keys to the radiation of angiosperms into freezing environments. Nature. 2014;506(7486):89-92. https://doi.org/10.1038/nature12872.

36. Huenneke LF, Anderson JP, Remmenga M, Schlesinger WH. Desertification alters patterns of aboveground net primary production in chihuahuan ecosystem. Glob. Change Biol. 2002;8(3):247-64. https://doi.org/10.1046/j.13 65-2486.2002.00473.x.

37. Fravolini A, Hultine KR, Brugnoli E, Gazal R, English NB, Williams DG. Precipitation pulse use by an invasive woody legume: the role of soil texture and pulse size. Oecologia. 2005;144(4):618-27. https://doi.org/10.1 007/s00442-005-0078-4.

38. Zhong ZW, Li XF, Pearson D, Wang DL, Sanders D, Zhu Y, Wang L. Ecosystem engineering strengthens bottom-up and weakens top-down effects via trait-mediated indirect interactions. Proc R Soc B-Biol Sci. 2017; 284(1863):20170894. https://doi.org/10.1098/rspb.2017.0894.

39. Gao S, Wang JF, Knops JMH, Wang J. Nitrogen addition increases sexual reproduction and improves seedling growth in the perennial rhizomatous grass Leymus chinensis. BMC Plant Biol. 2020;20(1):106. https://doi.org/10.11 86/s12870-020-2307-8

40. Giese M, Gao YZ, Zhao Y, Pan QM, Lin S, Peth S, Brueck H. Effects of grazing and rainfall variability on root and shoot decomposition in a semi-arid grassland. Appl Soil Ecol. 2009;41(1):8-18. https://doi.org/10.1016/j.apsoil.2 008.08.002.

41. Jiri D, Veronika J, Martin M, Pierre L. Contrasting biomass allocation responses across ontogeny and stress gradients reveal plant adaptations to drought and cold. Funct Ecol. 2021;35:32-42.

\section{Publisher's Note}

Springer Nature remains neutral with regard to jurisdictional claims in published maps and institutional affiliations.

Ready to submit your research? Choose BMC and benefit from:

- fast, convenient online submission

- thorough peer review by experienced researchers in your field

- rapid publication on acceptance

- support for research data, including large and complex data types

- gold Open Access which fosters wider collaboration and increased citations

- maximum visibility for your research: over $100 \mathrm{M}$ website views per year

At BMC, research is always in progress.

Learn more biomedcentral.com/submissions 